\title{
UTILIZATION OF ANAEROBIC MICROBIOLOGY TO IMPROVE ANIMAL PRODUCTION
}

\author{
H.M. Gado
}

Department of Animal Production, Faculty of Agriculture, Ain Shams University

Received: 29/8/2019

Accepted: 14/10/2019

\section{INTRODUCTION}

Anaerobic probiotic treatments are new technology for improving the nutritive value of lignocellulose materials which are the most abundant in agricultural residues and to elevate animal performance. The attachment of microbes to feed particles and the nitrogenous substances play important roles in the biosynthesis of protein by different organisms. Thus, in order to increase digestibility of these roughages, it is important to break the linkage between cellulose, hemi-cellulose and lignin or to degrade the compact nature of the tissue. There have been attempts to do that by mechanical, chemical or biological treatments and enriching treatments (Gado et al., 2017).

Probiotics are live microorganisms that confer health benefits to the host, and are generally regarded as safe. The anaerobic bacteria sources associated probiotics have better performance than fungi sources with animals (Gado et al., 2017). Exogenous fibrolytic enzymes might enhance attachment and/or improve access to the cell wall matrix by ruminal microorganisms and by doing so, accelerate the rate of digestion. Pobiotics have been recently used in the ruminant rations to degrade fiber contents to make it easier for digestion, to be more useful for the micro-organisms and flora which are the main source of the microbial protein in the ruminal media and to reduce the costs of the ration.

This article, aims to document the impact of probiotic (ZAD) on by-products utilization, nutritional aspects, animal performances and other physiological aspects of ruminant and non-ruminant animals.

Probiotic ZAD:

The probiotic product of $\mathrm{ZAD}^{\circledR}$ is a liquid biotechnical product made from natural sources of bacteria to elevate the level of multi-enzyme such as cellulase, xylanzses etc. Enzymes released from anaerobic bacteria which can convert the polysaccharide into monosaccharide by specific enzymes, such as cellulase, hemicellulase, amylase and protease. The product is intended to provide tools to improve the nutritive value for fibrous materials through $\mathrm{ZAD}^{\circledR}$ and $\mathrm{ZADO}^{\circledR}$ (powder) is designed to improve the rumen kinetics and overall animal digestion. The $\mathrm{ZAD}^{\circledR}$ is used in treating a lot of agricultural by-products such as rice straw, corn stalks, bagasse, etc. beside feeding animals. This mix between anaerobic bacteria and those by-products ended up making improved products from the nutritive point of view, which provides a new line of animal feed that will help in reducing the feed cost. The anaerobic bacteria of ZAD helped in breaking down the secondary compounds in the feed. It also increases the microbial populations, which will lead to an increase in the microbial protein either in the reticulo-rumen area or by-pass through the digestive tract. An increase in the total volatile fatty acids is noticed. In some research work an improvement in the animal's immunity is observed. An improvement in the total digestible nutrients of the ration is recorded in all trials.

\section{In vitro gas production}

In vitro gas production (GP) relates to the chemical composition of the feed, in particular to the fiber content and its structural polysaccharides. Several studies have shown that adding this probiotic preparation to ruminant diets increased digestion of DM and fibre measured in situ, in vitro or in vivo trials. Increased in vitro GP with $\mathrm{ZAD}$ may allow higher voluntary feed intake by decreasing physical rumen fill.

Elghandour et al. (2013) and López et al. (2013)evaluated the influence of an probiotic mixture (ZADO) on in vitro gas production (GP), in vitro dry matter degradability (DMD), metabolizable energy (ME) and short chain fatty acid (SCFA) production in growing lambs fed a high concentrate diet. Results reported that addition of exogenous enzymes (probiotic) has a potential impacts on improving the nutritive utilization of high concentrate diet fed to growing animals due improving the ruminal activities.

Plant extracts, rich in secondary metabolites, have been used as feed additives in order to manipulate ruminal fermentation and improve the efficiency of nutrients use, by decreasing the amount of methane or ammonia $\mathrm{N}$ produced. Secondary metabolites, such as essential oils, can modify rumen $\mathrm{N}$ metabolism by reducing degradation of proteins, and ammonia production in the rumen. Salem et al. (2014) studied the effect of different doses of plant extracts when combined with exogenous fibrolytic enzymes (probiotic) on in vitro ruminal fermentation. Results reported that in vitro gas production and ruminal fermentation contribute to highlight that extract of $S$. babylonica, when added at high doses are promising potential modifiers of in vitro ruminal 
fermentation. However, when added simultaneously with fibrolytic enzymes (individual or mixture) they generally lose their beneficial effects on pattern of fermentation and in vitro gas production parameters.

\section{Fiber digestibility:}

Digestion of plant cell walls in fibrous feeds by ruminants is possible mainly due to the enzymes produced by ruminal bacteria, protozoa and fungi. Fibrous feeds have high cellulose and hemicellulose concentrations that can create a complex of structural carbohydrates and lignin to reduce the digestibility of the carbohydrates and reduce efficient utilization of forages by ruminants. Exogenous fibrolytic enzymes (probiotic) may improve the nutritive value of fibrous feeds due to enhanced attachment by rumen microorganisms.

However, the addition of exogenous enzyme (probiotic) is influenced by factors such as diet composition, type of enzyme preparation, enzyme stability, specific enzyme activities, method of application and amount of enzyme added. Several studies have focused on improving agricultural byproducts digestibility in vitro and increase fiber digestion and utilization by adding the probiotic ZAD as liquid or ZADO in powder form.

The effect of anaerobic probiotic treatments on nutritive value of rice straw and sugar cane bagasse, rumen liquor and blood parameters were studied. Results concluded that the probiotic treatments increased protein content, protein digestibility and fiber degradation and improved its chemical composition(Gado et al., 2006 and Gado et al., 2007).

Also, Gado and Borhami (2010) reported that 3L ZAD applied at ensiling can improve the digestibility, fermentation, and aerobic constancy of rice straw silage. The previous results are in agreement with Gado et al. (2017) who reported that ensiling fibers of wheat straw, cornstalks and sugarcane bagasse with ZAD improved and enhanced their ruminal digestion with the biodegradation rate at $3 \mathrm{~L} /$ ton and subsequently produced a cleaner product for animal feed from agriculture wastes.

Distillers dried grains with soluble (DDGS) are highly valued as an animal feed for its nutrient content. High protein and high energy content make distillers DDGS a unique ingredient for ruminant diets, but variation in composition reduces nutritional quality and market value. According to Gado et al. (2013) ensiling rice straw, DDGS or their mixture with $3 \mathrm{~L} /$ ton of probiotic $\mathrm{ZAD}$ showed strong potential in improving the degradation of fibrous and dry matter.

\section{Effect on meat production:}

Feeding cattle on diets supplemented with anaerobic probiotic contain fiber-degrading enzymes (ZAD or ZADO) can improve feed utilization and animal performance by enhancing fiber degradation. Direct-fed enzymes have been shown to enhance microbial colonization of feeds by increasing numbers of ruminal fibrolytic microbe. Addition of the anaerobic probiotic (exogenous enzymes) product to steers fed a TMR increased live-weight gain by $16 \%$ due to enhanced ruminal fermentation and digestion as well as increased total purine derivatives (Salem et al., 2013).

The effect of the anaerobic probiotic treatment of some agricultural by-products on the performance of lambs were studied. Wheat and bean straws treated with 2L/ton of ZAD (Fatma et al., 2005) improved the digestibility coefficients, feeding values, growth performance and final body weight of the ram lambs, Gad et al. (2005) had the same results when studied the effect of ZAD on corn straw and bagasse. (Atriplex halimus) silage treated with ZAD improved digestibility and rumen fermentation in sheep (Alsersy et al., 2015).

Supplementing ruminant diets with ZADO (exogenous enzyme) could improve feed intake, improve rumen fermentation, increase nutrient digestion, improve feed efficiency and finally increase animal performance under the critical conditions of shortage feedstuffs in Egypt (Gado and Borhami, 2011; Salem et al., 2011; El-bassiouny et al., 2018; Hassan et al.,2019). Moreover, pretreatment the fibrous feed with anaerobic probiotic for $24 \mathrm{~h}$ could improve the ruminal fermentation and fiber degradability in sheep compared to the direct addition in diets (Salem et al., 2012).

Ensiling orange pulp with anaerobic probiotic improved the lamb's average daily gain by $92 \%$ and digestible DM by $18 \%$. Furthermore, addition of ZADO to the orange pulp could improve the animal immunity and health, (Gado et al., 2011; Salem et al.,2011). Adding either ZAD, orange pulp or both to Rice straw with barley sprout increased TDN by $16 \%$ and digestibility of crude protein by $20 \%$ without any abnormal signs on blood and rumen parameters (Gomaa et al., 2012).

Plant extracts rich in secondary compounds have been shown to have positive effects on daily gain, voluntary feed intake, milk production and ruminal fermentation parameters. These benefits were studied with addition of ZAD on sheep performance and meat quality, which reported that the combination of Salix abylonica (SB) extract enzymes as additives improved meat $\mathrm{pH}$ and color compared to the control or individual additives which resulted in a more favorable color and might contribute to a better conservation profile (Cayetano et al., 2013), no effect on hematological parameters of lamb as an indicator of health status (Rivero et al., 2012) and ZAD and SB have a positive effect on immunity in animals (Rivero et al., 2013).

Treatment of bagasse had a great effect on increasing crude protein content and increasing degrading crude fiber content, which resulted in improving average daily gain, feed efficiency, digestibility and feeding values for goats (Gado et al., 
2007). moreover, using wheat straw treated chemically with (3\% urea and 3\% molasses) then biologically with (ZAD solution, 1L/Ton) in lactating and growing goats, improved TDN and digestible crude protein and seem to be good economically (Sabbah et al.,2009).

Addition of ZADO ${ }^{\circledR}$ enzymes improved nutrients digestibility in sheep and goats. The improvement was better in goats than in sheep. Goats had the lowest total dry matter intake that associated with an improvement in nutrient digestibility and average daily gain more than sheep. These results suggested a good performance of goats than sheep under the critical conditions of shortage feedstuffs during the dry season in Egypt (Salem et al., 2011).

The anaerobic probiotic product $\left(\mathrm{ZADO}^{\circledR}\right)$ when added to camel rations, increased daily gain due to enhanced nutrient intake, and nutrient digestibility, as well as increased feed conversation. Moreover, adding ZADO ${ }^{\circ}$ in camel ration $(40 \mathrm{~g} / \mathrm{h} / \mathrm{d})$ was the better, as confirmed by the highest body weight gain, most of blood metabolites and digestibility (Adel and El-Metwaly., 2012).

\section{Effect on milk production:}

Positive effects of adding anaerobic probiotic to ruminant diets have been reported for lactating dairy cows and growing cattle. Gado et al. (2009) evaluate the effect of $\mathrm{ZADO}^{\circledR}$ on milk production and composition, rumianl fermentation activities and nutrients digestibility in dairy cows, lactating Brown Swiss cows were fed a mixed ration with or without addition of $40 \mathrm{~g} / \mathrm{head} / \mathrm{d} \quad \mathrm{ZADO}^{\circledR}$. Digestibility coefficients of DM, OM, NDF and ADF were improved by addition $\mathrm{ZADO}^{\circledR}$ in cow diet, consequently, total milk yield, 3.5 and $4 \%$ fat corrected milk and energy corrected milk improved. It could be concluded that supplementing dairy cow diets with $\mathrm{ZADO}^{\circledR}$ has the potential to enhance milk yield as a consequence for improving the nutrients digestibility, ruminal fermentation activities and microbial protein synthesis.

Also, Gado et al. (2012) had the same results where lactating Holstein dairy cows fed on diet supplemented with ZADO increased milk production in comparison to control or yeast supplemented diets.

Exposure of pregnant buffaloes to stress of cold waves during winter affects physiological functions as increased rate of respiration rate (RR) and heat dissipation(HD). Incorporating the fibrolytic enzymes of ZAD $(5 \mathrm{~g} / \mathrm{h} /$ day) into diet of buffaloes have the ability to maintain their heat balance evidenced by reduced values of RR and HD particularly after calving. Moreover, ZAD treated group had increased thyroid concomitant with enhanced metabolic activity and increased milk production with greater fat percentage. It could be concluded that use of supplementing diets with ZAD reduced the harmful effects of cold waves, help to improve physiological status at postpartum and reduces sensitivity of buffaloes to cooling with climatic changes (Fayza et al., 2017).
Khattab et al. (2011) studied the feeding value of partial replacement of Berseem Clover (BC) by treated sun dried rumen contents (DRC) with a mixture of exogenous enzymes $\left(Z A \mathrm{ADO}^{\circledR}\right.$ or $\left.\mathrm{ZAD}^{\circledR}\right)$ from anaerobic bacteria in the ration of early lactating Baladi goats. Biological treated groups recorded higher values of digestibility coefficients, increasing daily milk yield, $4 \%$ fat corrected milk, fat, total solids, solids not fat and lactose yields. The study recommended that feeding goats on rations containing DRC treated with ZADO and/or ZAD as a partial substitute of berseem improved the performance of lactating goats without any adverse effect on animals' health.

Heat load conditions may induce declines in milk yield, milk fat and protein contents in lactating sheep. Gado et al. (2014) studied the effects of vitamin mixtures and exogenous enzymes $\mathrm{ZADO}^{\circledR}$ in alleviating heat stress in ewes in summer temperatures $\left(25-44^{\circ} \mathrm{C}\right)$ compared with winter temperatures $\left(8-22^{\circ} \mathrm{C}\right)$. The results showed that addition of $\mathrm{ZADO}^{\circledR}$ increased plasma total protein, glucose, milk production, protein and lactose in treated groups compared with summer control. Vitamin mixture increased plasma total protein, milk production and milk protein. Combination of vitamin mixture with $\mathrm{ZADO}^{\circledR}$ addition increased the ability of lactating ewes to alleviate heat stress as evident by increased plasma parameters and milk production during the summer season. So it is recommended to add probiotic ZAD and/or mixture of vitamins to lactating sheep diets especially during heat stress.

\section{Effect on reproduction:}

Ossimi sheep was the tested species to study the effect of probotic ZAD on the reproduction performance uptill now, where Abdalla et al. (2012) studied the effect of dietary of supplementation of melatonin $(3 \mathrm{mg} / \mathrm{h} / \mathrm{d})$, ZADO $(15 \mathrm{~g} / \mathrm{h} / \mathrm{d})$ and their combination on the reproduction performance of Ossimi ewes. The results reported that the groups fed melatonin alone or with ZADO showed better reproductive performance and lambed ewes.

Moreover, the dietary supplementation of probiotic ZAD was evaluated in another study to improve nutritional status and consequently will improve semen quality characteristics in Ossimi rams. The study recommended that feeding rams on ration containing ZAD compound had a beneficial effect on their semen quality characteristics, blood parameters and generally on reproductive performance (Abdalla et al., 2012)

Gado et al.(2015) studied the effect of ZADO on semen characteristics, sexual hormones and libido of HY-plus rabbit bucks,. whereas the tested animals fed the basal diet supplemented ZADO with 4 levels $(0,1,3,5 \mathrm{~kg} /$ ton $)$. The results revelaed that the probiotic addition improved the sexual activity, spermatozoa production and quality of HY-plus rabbit bucks. The study recommended that addition the probiotic ZADO with $5 \mathrm{~kg} / \mathrm{ton}$ in diets of rabbit 
bucks was effective to improve both semen characteristics and sexual drive.

Also, the effect of probiotic ZADO on HY-plus rabbit does was studied. The addition of ZADO to commercial diet increased conception and kindling rate, litter size, weight at birth and bunny weight at weaning, while decreased abortion rate and preweaning mortality. Moreover, total milk yield increased and sings of vitality were improved with ZADO addition. the supplementation of ZADO with $5 \mathrm{~kg} / \mathrm{ton}$ in rabbit diets were more effective to improve the reproductive performance and milk output in rabbit does (Gado et al., 2016).

\section{Effect on Fish:}

Adding probiotic ZAD in fish diets showed an improvement in fish production final body weight, total weight gain, gain percent and specific growth rate, in Nile tilapia fry (Abu-Ayyana et al.,2017)..

\section{Effect on Poultry:}

Broiler diets supplemented with $0.5 \mathrm{Kg}$ of $\mathrm{ZADO}^{\circledR}$ improved broiler productivity from hatch to 42 days of age. In addition, $\mathrm{ZADO}^{\circledR}$ supplementation improves broiler immunity. ZADO ${ }^{\circledR}$ products are very safe on birds and accordingly birds are safe for human consumption (Hosam, 2013 and El-Sanhoury and Ahmed, 2017). laying hens' diets supplemented with $Z A D O \circledast$ might increase plasma protein and enhance enzymes activity which might reflect into slight increase in hens' productivity (Hosam et al., 2019).

\section{CONCLUSION}

1. The potential of enzymatic action on agriculture by-products is valid.

2. The animal response in dairy or beef production is very clear and strong.

3. The improvement in animal production is about to enter a new dynasty and research in this area will benefit of all human kind.

\section{REFERENCES}

Abdalla, E.B., A.Q. Al-Momani, F.A. Khalil, H.M. Gado and F.S. Al-Barakeh, 2012. Improving reproductive performance of Ossimi ewes using hormonal and enzymatic treatments. Annual meeting of ASAS \& ADSA, Abstract.

Abdalla, E.B., F.R. Abed El-Aziz, H.M. Gado, A.E. Hassan and M.S. Ziada, 2012. Reproductive performance of Ossimi rams fed biologically treated rations. Annual meeting of ASAS \& ADSA, Abstract.

Abu-Ayyana,A.K.A., T.M.A. Srour, M.A.A. Zaki and A.T. Mansour,2017. Enhancing the Utilization of Olive Cake Treated with Different Probiotic Exogenous Fibrolytic Enzymes $(Z A D \AA)$ Concentrations in Nile Tilapia Diets. J. Adv. Agric. Res., 22(4):760-774.
Adel, E.M. and H. EL-Metwaly, 2012. Effect of feed additive "Exogenous Enzymes" on growth performance of Maghraby Camels. Life Sci. J., 9(4): 4837-4842.

Alsersy, H., A. Z.M. Salem, B.E. Borhami, J. Olivares, H.M. Gado, M.D. Mariezcurrena, M.H. Yacuot, A.E. Kholif, M. El-adawy and S.R. Hernandez, 2015. Effect of Mediterranean saltbush (Atriplex halimus)ensilaging with two developed enzyme cocktails onfeed intake, nutrient digestibility and ruminalfermentation in sheep. Anim. Sci. J., 86: 51-58.

Cayetano, J.A., A.Z.M. Salem, B.M.A. Mariezcurrena, R. Rojo, M.A. Cerrillo-Soto, H. Gado and L.M. Camacho, 2013. Effect of adding Salix babylonica Extracts and Exogenous Enzymes to Basal Diets on the Meat Quality of Growing Suffolk Lambs. Anim. Nutr. Feed Technol., 13: 373-380.

El-Bassiouny, M.F., A.S. El-Hawy, R.A. AbdElazem, A. Abdou, 2018. Blood biochemical changes and thyroid hormones pattern of Barki ewes as affected by biological supplementation under semi-arid conditions of Egypt. Research Journal of Animal and Veterinary Sciences, 10(1): 13-20.

Elghandour, M.M.Y., A.Z.M. Salem, M. GonzalezRonquillo, J.L. Bórquez, H.M. Gado, N.E. Odongo, C.G. Penuelas, 2013. Effects of exogenous enzymes on in vitro gas production kinetics and ruminal fermentation of four fibrous feeds. Anim. Feed Sci. Technol., 179: 46-53.

El-Sanhoury M.H.S. and A.M.H. Ahmed, 2017. Broiler performance, enzymes activity and histological observations affected by multi enzymes complex (ZADO®). Egyptian J. Nutrition and Feeds, 20(2): 251-262.

Fayza, O.I., A.A.S. Mahgoub and T.A. Fooda, 2017. Effect of biological additive on physiological and productive performance of buffaloes during cold waves stress in mid of the egyptian valley. Egypt. J. Agric. Res., 95 (4): 1819-1830.

Gad, A.M., H, Gado and H.M. Metwally, 2005. Effect of ZAD as a biological additive on the performance of small ruminants fed rations based on agricultural byproducts. Research Bulletin, Ain Shams Univ., 2005.

Gado H., M. Mellado, A.Z.M. Salem, A. Zaragoza and T.S.T Seleem, 2015. Semen characteristics, sexual hormones and libido of Hy-plus rabbit bucks influenced by a dietary multi enzyme additive. World Rabbit Sci.,23: 111-120.

Gado, H., B.E. Borhami and A.Z.M. Salem, 2012. The potential benefits of supplementing cornbased dairy diets with ZADO or yeast for milk yield and production efficiency in dairy cows. Annual meeting of ASAS \& ADSA, Abstract.

Gado, H.M, S.A. Nasr, K.B. Mobamed and A.A. Mahrous, 2006.Effect of biological treatments on the nutritive value of rice straw. Egyptian J. Nutrition and Feeds, 9(2): 207-219. 
Gado, H.M. , A.Z.M. Salem, P.H. Robinson, M. Hassan, 2009. Influence of exogenous enzymes on nutrient digestibility, extent of ruminal fermentation as well as milk production and composition in dairy cows. Anim. Feed Sci. Technol., 154: 36-46.

Gado, H.M. and B. E. Borhami, 2010.Effect of anaerobic enzyme matrix on fiber digestibility. Annual meeting of ASAS \& ADSA 2010, Abstract.

Gado, H.M., A. Khusro and A.Z.M. Salem, 2017. Role of probiotics in animal nutrition: A review. Animal review, 4(1): 8-20.

Gado, H.M., A.E. Kholif, A.Z.M. Salem and M.M.M. Elghandour, 2016. Fertility, mortality, milk output, and body thermoregulation of growing Hy-Plus rabbits fed on diets supplemented with multi-enzymes preparation. Trop. Anim. Health Prod., 48:1375-1380.

Gado, H.M., A.Z.M. Salem, L.M.Camacho, M.M.Y. Elghandour, M.C. Salazar, 2013. Influence of exogenous enzymes of $Z A D \AA$ on in vitro ruminal degradation of ensiled rice straw with DDGS. Anim. Nutr. Feed Technol., 13: 569-574.

Gado, H.M., A.Z.M. Salem, N.E. Odongo, B.E. Borhami, 2011. Influence of exogenous enzymes ensiled with orange pulp on digestion and growth performance in lambs. Anim. Feed Sci. Technol., 165:131-136.

Gado, H.M., H.M. Metwally, A.A. El-Basiony, H.S. Soliman and E.R.Abd El-Galil, 2007.Enzymatic treatments of sugarcane bagasse by different sources of cellulose enzymes. Egyptian J. Nutrition and Feeds, 10(2): 607-620.

Gado, H.M., H.M. Metwally, A.Z. El Basiony, H.S. Soliman and E.RI.Abd El Galil, 2007.Effect of biological treatments on sugarcane bagasse digestibility and performance of Baladi goats. Egyptian J. Nutrition and Feeds, 10(2): 535-551.

Gado, H.M., M.M.Y. Elghandour, M. Cipriano, N.E. Odongo and A.Z.M. Salem, 2017. Rumen degradation and nutritive utilization of wheat straw, cornstalks and Sugar cane bagasse ensiled with multi enzymes. Journal of applied animal research, 45(1): 485-489.

Gado, H.M., S.S. Almustafa, A.Z. Salem, F.A. Khalil, 2014. Influence of Vitamins and Exogenous Enzymes Combination on alleviating Heat Stress in actating Ewes under Egyptian Summer Conditions. Anim. Nutr. Feed Technol., 14: 195-203.

Gomaa, R., H. Gado, H. El-Sayed and S. Abd ElMawla, 2012. Usage of treated rice straw with exogenous anaerobic bacterial enzymes (ZAD) for Ossimi sheep. Annals of Agri. Sci., 57(2): 183-190.

Hassan, A., H. Gado, U.Y. Anele, M.A.M. Berasain and A.Z.M. Salem, 2019. Influence of dietary probiotic inclusion on growth performance, nutrient utilization, ruminal fermentation activities and methane production in growing lambs. Animal Biotechnology, 21: 1-8.
Hosam, M.S., 2013. Influence of Dietary Enzymes Prepared at Ensiling $(Z A D O \otimes)$ from Hatch to 42 Days of Age on Productivity, Slaughter Traits and Blood Constituents in Broiler Chickens. International Journal of Poultry Science 12 (9): 529-537.

Hosam, M.S., H.R. Elsherif, M.H. Elsanhoury, A.M. Fouad, M.A. Elmenawey and A.O. Abass, 2019. Impact of Dietary Enzymes Prepared at Ensiling $(Z A D O \AA)$ on Productivity, Blood Metabolites and Enzymes Activity in Commercial Laying Hens. International Journal of Poultry Science, 10: 276-283.

Khattab, H.M., H.M. Gado, A.E. Kholif, A.M. Mansour and A.M. Kholif, 2011. The Potential of Feeding Goats Sun Dried Rumen Contents with or without Bacterial Inoculums as Replacement for Berseem Clover and the Effects on Milk Production and Animal Health. International Journal of Dairy Science 6 (5): 267-277.

López, D., M.M.Y. Elghandour, A.Z.M. Salem, J.F. Vázquez-Armijo, M.C. Salazar and H.M. Gado, 2013.Influence of Exogenous Enzymes on In Vitro Gas Production Kinetics and Dry Matter Degradability of a High Concentrate Diet. Anim. Nutr. Feed Technol., 13: 527-536.

Ramadan, F., H.M. Gado, M. Muurad and B.B. Matter, 2005. Effect of some biological treatments of some agricultural byproducts on ration digestibility and lamb performance. Research Bulletin, Ain Shams Uni., 2005.

Rivero, N., A.Z.M. Salem, M.G. Ronquillo, M.A. Cerrillo-Soto, L.M. Camacho, H. Gado and C.G. Peñuelas, 2013. Effects of Exogenous Enzymes and Salix babylonica L. Extract on Cellular Immune Response and its Correlation with Average Daily Weight Gain in Growing Lambs. Anim. Nutr. Feed Technol., 13: 411-422.

Sabbah, M. Allam,H.M. El-Shaer, K.M. Youssef,M.A. Ali and S.Y.AboBakr, 2009.Impact of Feeding Biologically Treated Wheat Straw onthe Production Performance of Goats in North Sinai. World Journal of Agricultural Sciences 5 (5): 535-543.

Salem, A. Z. M., A. A. Hassan, M. S. Khalil, H. M. Gado, H. Alsersy, and J. Simbaya, 2012. Effects of sun-drying and exogenous enzymes on nutrients intake, digestibility and nitrogen utilization in sheep fed Atriplex halimus foliages, Anim. Feed Sci. Technol., 171: 128-135.

Salem, A.Z.M., G. Buendia, M.M.Y. Elghandour, M.A.M. Berasain, H.M. Gado, H. Ammar and M.A. Rodríguez, 2014. Effects of Cellulase and Xylanase Enzymes Mixed with Increasing Doses of Salix babylonica Extract on in vitro Gas Production Kinetics of a Mixture of Corn Silage with Concentrate. Journal of Integrative Agriculture, 3119(13): 60732-7.

Salem, A.Z.M., H.M. Gado, D. Colombatto, M.M.Y. Elghandour, 2013. Effects of exogenous enzymes on nutrient digestibility, ruminal fermentation and 
growth performance in beef steers. Lives Sci.154:69-73.

Salem, A.Z.M., M. El-Adawy, H. Gado, L.M. Camacho, M. González-Ronquillo, H. Alsersy, B. Borhami, 2011. Effect of exogenous enzymes on nutrients digestibility and growth performance in sheep and goats. Tropical and Subtropical Agroecosystems, 14: 867-874.
Salem,A.Z.M., M.M. El-Adawy, H. Gado, and M.S.M. Khalil, 2007.Feed intake, nutrient digestibility and animal growth performance in sheep and goats fed wheat straw, ADSA PSA AMPA ASAS Joint Annual Meeting, San Antonio, TX, USA, July 8-12. Journal of Animal Science, 85: 107. 